IJOTL TL, Vol. 3, No. 3, September 2018

p ISSN: 2502 2326; e ISSN: 2502 8278

Http://ijolt1.pusatbahasa.or.id; Email: ijolt1@gmail.com

Center of Language and Culture Studies, Surakarta, Indonesia

Armadi, Samsu. 2018. Reading Comprehension and Vocabulary Mastery of the Sixth Graders of SDN O3 Tenggarong. IJOTL TL (2018), 3(3): 123 132. DOI: 10.30957/ijotl tl.v3i3.503.

\title{
READING COMPREHENSION AND VOCABULARY MASTERY OF THE SIXTH GRADERS OF SDN 03 TENGGARONG
}

\author{
Samsu Armadi \\ University of Kutai Kartanegara \\ Jl. Gunung Kombeng 27 Tenggarong, Kalimantan Timur \\ Email: samsuarmadi@gmail.com
}

\begin{abstract}
This article describes the result of study on the relationship between reading comprehension to vocabulary mastery. Using correlational design, this study assigned 84 students of the sixth grade students of SDN 03 Tenggarong as the sample. The instruments of this study were test on reading comprehension and test on vocabulary mastery. Two kinds of data in terms of scores on reading comprehension and scores on vocabulary mastery were analyzed using product moment formula at $\mathrm{p}=0.05$ and $\mathrm{N}=84$. The study revealed that $\mathrm{r}$-value was .802 and $\mathrm{r}$-table was .294 $(\mathrm{p}=0.05)$. The hypothesis testing indicated that $\mathrm{r}$-value was greater than $\mathrm{r}-$ table. The evidence showed that the study was significant, meaning that reading comprehension significantly relates to vocabulary mastery. The higher scores on reading comprehension allowed higher scores on vocabulary.
\end{abstract}

Key-words: correlation, reading comprehension, vocabulary mastery.

DOI: $10.30957 /$ ijotl tl.v3i3.503

\section{INTRODUCTION}

In Indonesia, English language has been determined as a compulsory subject to be thought from secondary school to university level since long time ago. Although it has been thought to many students on every level of education, only some of them can use either written or orally. Introducing English as early as possible is good way of elementary school (SD) system of education so that attempt must be a positive traditionally English lesson. Where English is taught as a foreign language in Indonesia, the teaching learning of English is of particular importance. It is taught from elementary school to university.

One of the most significant aspects on language development is vocabulary, because it is a key to all language expression, either oral or written. One expresses his idea to other by using words. On the other hand, one understands other people by using words, too. So, achieving vocabulary is an important thing in learning English, although no specific treatment is given in the teaching-learning process. However, without 
vocabulary, no meaning is achieved. Vocabulary list is given in the 1994 English Curriculum, but how the words should be taught is not described in the curriculum.

In addition, reading is very important in modern life nowadays. The importance of reading is giving information, news, and knowledge. The role of reading is like an open gateway. It also makes our world is wider than our immediate surroundings provide. Through reading, we can learn cultures and give us power to revolutionize our ways of thinking and living. It helps the individual to understand the society and his role as a citizen, and a worker, with his own personal needs and problems. Thus, reading is very valuable skill that the average person learns in his/her life time.

\section{LITERATURE REVIEW}

\subsection{Reading Comprehension}

Reading is the act of responding with appropriate meaning to be printed or written verbal symbols (Harris, 1984). Reading is passive act of communication. It means that the reader only receives what the author has written. On the other side, there is an active process of communication in the readers' brain. Hafner (1967:457) said that reading is an active process that required the individual to demand meaning and to bring ideas to the printed page, so that symbols trigger off meaning according to the pattern of writing and experience and intelligence and habit inquiry of the readers.

According to Lado (1964:132) states that reading is as an action. Language patterns from the author's representation. While Moore (1983:3) describes that reading as getting meaning from written text or comprehension. But, Jeremy Harmer (1983:16) thinks that reading is receptive skill where the reader is receiving written in a language. Thus, reading is not only an activity that involves eyes to see and tongues to pronounce the word, but full concentration as well to get the information of the message encode by a writer in written language.

Therefore, reading activity involves: (1) the background experience of the reader, (2) the accuracy with which the reader responds to printed or written materials, and (3) the reader understands the message. So the writer concludes that reading is the activity of getting meaning and understanding the written text also without fully vocabulary mastery very little can be convey and comprehend from message.

The definition of reading comprehension was presented by Baudion (1977:15) that states reading for thorough comprehension is careful reading in order to understand the total meaning of the passage. While Grellet, (1984:3) expresses that understanding a written text means extracting the required information from it as efficiently as possible. Miller and Laird (1979: 20) states that the aim of comprehension system should be translated the linguistic input into routines for action in accordance with the social context of it is part.

Furthermore, Moore (1983:3) describes that reading is as getting meaning from written text or comprehension. In the elementary school, reading in English is the activity to get meaning by translates the English words into native words. So reading in elementary school is the activity of translation of the words. The number of vocabulary is very influence the understanding the reading. 
From definition mentioned above, it can be concluded that reading comprehension is a reading for understanding and grasping the total meaning of the passage in depth in order to receive the ideas and information as well and as efficiently as possible.

\subsection{Process of Reading}

When we read a passage, we must find something in the reading context; understanding, information, pleasure, or others. Basically, when we want to understand the passage fully, we should have the ability to comprehend. In relation with reading skill, Button (1983:13) states comprehension is understanding in depth. It is grasping, a taking in of the material with which the readers are required to deal.

The performance that is resulted from reading follows some processes. The processes are related each other. According to Ishak (1994:8) states the processes are: mechanical process, meaningful process, experiential process, developmental process, and total growth process in which mechanical process, meaning development, and experience. Each plays has an important part.

Furthermore, Lawrence (1967:72) defines that comprehension is the ability to understand what one has read or listened. It means that in process of reading, the reader understands what the content is or what the writer conveys. There is assimilation among fact, concepts and generalizations of new term from what the readers have known. Thus, in reading students can improve their grammar, vocabulary and writing sentences. Therefore, the most materials in English subject at school are reading, especially reading comprehension.

\subsection{Kinds of Reading}

Reading can be done aloud or silently. In reading aloud, the reader enunciates the sounds which are symbolized by the writer's marks on the script. Reading aloud demands more clear pronunciation, how the reader pronounces the word correctly, includes rhythm: regular repetition of units or stress in time, and intonation: system of sentence and phrase or sentence that may be said with different intonation to express different shades of meaning or different attitudes.

While in silent reading, the reader will derive meaning from the word combinations in the text without necessarily vocalizing what he is reading. Silent reading does not insist on the intonation and rhythm, but observe the information as much as possible, and understand the meaning of sentences and ideas of the script.

For the purpose of comprehending the text, silent reading has to be occurred. This is based on Dwyer's opinion (1983:86) that reading aloud forced the students to focus on each word (not looking at the words as whole for communication) and make them struggle to pronounce correctly and deliver expressively what they are reading loudly.

Thereby, in reading students can improve their vocabulary. In this case, the students do not know simply know the lexical meaning of individual words, but they must develop strategies which will allow them to discover the meanings of the words additionally, they also practice deriving the meaning from the context (Abort, 1981:75). 
IJOTL $\sim$ TL, Vol. 3, No. 3, September 2018

p ISSN: 2502 2326; e ISSN: 2502 8278

Http://ijolt1.pusatbahasa.or.id; Email: ijolt1@gmail.com

Center of Language and Culture Studies, Surakarta, Indonesia

Armadi, Samsu. 2018. Reading Comprehension and Vocabulary Mastery of the Sixth Graders of SDN O3 Tenggarong. IJOTL TL (2018), 3(3): 123 132. DOI: 10.30957/ijotl tl.v3i3.503.

And also in reading, students can increase the fluency of their spelling. In spelling, the students usually pronounce the words while observing the printed forms. Then they try to recall the appearance of the words without looking at them. Finally, the words are written and checked.

\subsection{Vocabulary Mastery}

In order to clarify the meaning of vocabulary achievement, the writer presents firstly the concepts of vocabulary. According to Yerkes (1989:1598) vocabulary is a list or collection of words or phrases of a language, branch, science or the like, usually arranged in alphabetical order and designed. Then, Charter's idea quoted by Agustina (1999:7) states that "vocabulary is the content and function words of a language which are learned so thoroughly that they become a part of child understanding, speaking, and later on reading and writing." And she also states that, "vocabulary is words having meaning when heard or seen even though not produced by individual himself to communicate with others." From the concept of vocabulary explained above, it can be said in short that vocabulary is a group of words that must be learned by learners of language.

Another definition of vocabulary as Webster's New Wordbook Inc. in the workbook encyclopedia states, "vocabulary is all the words of language. Vocabulary is the sum of words used by a particular person, profession, etc. Vocabulary is a list of words and phrases usually arranged alphabetical and defined." According to Cobuild (1996:1232) states that vocabulary is the total number of words one knows in a particular language. In Oxford learners dictionary (Hornby, 1997:290) that vocabulary is defined as the total number of words in language, and the word known to a person and a list of words with their meanings especially at the back of a book used for teaching a foreign language. In short, vocabulary is a total number or words that (with rules for combining them) makes up a language.

Based on the definitions above, the writer concludes that vocabulary is not only words we use in real situation that we can find in ourselves various activities of our life, but also words that arise from particular circumstance of our life and work.

From the concept of vocabulary above, it can be said that in short vocabulary is a group of words that must be learned by the learners' of language. In the learningteaching process, the mastery is indicated by the degree of achieve a level of understanding about a topic. The mastery is mastered by using a command to do exercise or a test to see the understanding of a topic. The mastery is represented in terms of score. In this regard, the mastery is an achievement about a topic and the achievement is presented in scores given to see the understanding of a topic.

Most people feel that there is a common sense relationship between vocabulary and comprehension-message or composed of ideas, and ideas are expressed in words. Most theorist and researchers in education have assumed that vocabulary knowledge and reading are closely correlated, and numerous studies have shown the strong correlation between the two (Baker, 1995). 
In short, vocabulary mastery is achievement about the total number of words which (with rules for combining them) make up language and the achievement is presented in scores given to see the understanding of the total number of words.

Based on Gairns and Redman (1986:54) states that learning and teaching vocabulary can be based on its contend and strategies. The content deals with decision about contend. The selection is based on:

a. The course book

The course book will include the written and spoken texts, activities for the presentation and practice of grammatical structures and testing exercise.

\section{b. Supplementary materials}

Supplementary materials provided by educational institution or selected by the teacher himself. This may include texts, drills, narrative, role-play, exercise, video, etc.

c. The student

A wide range of an unanticipated and unpredictable item will inevitably surface from student inquiries, queries and errors.

\section{d. Specific vocabulary}

Specific vocabulary activities designed by the teacher for his/her particular group of student.

In teaching-learning process, teachers are suggested to familiarize students finding a new word using a technique. To familiarize students finding new words, the writer thinks that it would be better if the teachers know the principles of vocabulary development. Stahl in Agustina (1999:30) confirms three principles of vocabulary development. They are as follows:

\section{a. Definition and contextual information}

Some things that are teacher might do to provide definitional information include; teaching synonyms, teaching antonyms, rewriting definition, providing examples, providing non-examples, discussing the difference between the new world and related word. Similarly, a teacher could provide contextual information by; having students create sentences containing the target word, discussing the meaning of the same word in different sentences, creating a scenario, and silly questions.

b. Involve children in actively processing new word meaning

A second principle of effective vocabulary instruction relates to how active students are at constructing links between new information and previously known information. The processing that students can be involved includes associating processing, comprehension, and generating processing. 
IJOTL $\sim$ TL, Vol. 3, No. 3, September 2018

p ISSN: 2502 2326; e ISSN: 2502 8278

Http://ijolt1.pusatbahasa.or.id; Email: ijolt1@gmail.com

Center of Language and Culture Studies, Surakarta, Indonesia

Armadi, Samsu. 2018. Reading Comprehension and Vocabulary Mastery of the Sixth Graders of SDN O3 Tenggarong. IJOTL TL (2018), 3(3): 123 132. DOI: 10.30957/ijotl tl.v3i3.503.

c. Use discussion to actively teach word meaning

Use discussion adds an important dimension to vocabulary instruction. Some benefits that can be taken by students can learn from their peers, students can construct a good idea of a word's meaning from the partial knowledge of the entire class, and students can have a clear meaning of word.

\section{METHODS}

The design of this research is correlation design. The purpose of the design is to examine the relationship of one variable to the other one. The first variable under study is the score of reading comprehension as the independent variable, and the second variable is the score of vocabulary mastery as the dependent variable.

The population of this study is the sixth year students of SDN 003 Tenggarong. There are three classes of the sixth year students, namely 6-A, 6-B, and 6-C. The total number of the population is 112 students. A population is complete set of individuals or subject having some common observable characteristics. The population may be all individuals or particular type or a more restrict part of the group (Moore, 1983:110). To observe the population, however, the researcher did not take the whole number of population, but it was a part of population as a sample.

Sample is a part of the population representing the characteristics of the population (Budiharso, 2004:154). The number of the sample is selected based on the opinion by Best (1985:57). If the subject is less than 100, it is better to take all, so the research is population research. In this study, because the total number of the population is more than 100 , the researcher took the sample $40 \%$ of population, so the total number of sample in this study was $40 \%$ x $112=44,8$ that was rounded off to 45 students. In this case, the sample of the research can be taken from fourteen to sixteen students each class, so the total number of sample is 45 students from three classes.

The instruments of this study are reading comprehension test and vocabulary mastery test. The profile of reading comprehension and vocabulary mastery test are described in the following sections.

The test of reading comprehension was designed based on the English textbook for sixth year students of elementary school (SD), such as English for Sekolah Dasar by Partini (2001). The format of the reading comprehension test is objective test because of the practical reason that the objective test is easy to score. The test is multiple-choice test, because multiple-choice test can be very consistent although it covers a very limited area of the content (Horrison, 1983:111). The test consists of 25 items from three passages. Each item has four choices.

The test of vocabulary mastery was designed based on the English textbook for the sixth year students of elementary school. Similar to reading test, the format of the vocabulary test is objective test because of the practical reason that the objective test is easy to score. The test is multiple-choice test and consists of 40 items. Each item has four choices, one number is the right answer and the others are cheaters.

In the case of obtaining a good test, the researcher applied a series of tryout before conducting the research. The tryout test applied is used to gain difficulty index, 
validity, and reliability. The tryout was conducted to select items of reading comprehension and vocabulary mastery tests.

There are two kinds of data used for this study, namely data on reading comprehension and data on vocabulary mastery. Data were collected based on the following procedures before analyzing by Product Moment Formula to see the correlation of the independent variable (reading comprehension) to the dependent variable (vocabulary mastery) of the study.

The data of reading comprehension is the score of reading comprehension test that was given to the sample. The highest score of reading test was 100, but the score of each items test based on number of test after the test to be selected based on the tryout analysis. The data of vocabulary mastery is the score of vocabulary mastery test that was given to the sample. The highest score of vocabulary test was 100, but the score of each items test based on number of test after the test to be selected based on the tryout analysis.

The research belongs to a correlation study, which aims at seeing whether reading comprehension has a close relationship with vocabulary mastery, so the equipment employed to analyze the data is the Product Moment Correlation formula under Karl Pearson. The formula used to correlate the variables was Pearson Product Moment formula. The test of the study was given under 5\% level of significance ( $\mathrm{p}=0.05$ ), and the value of $\mathrm{r}$-table at $\mathrm{N}=45$ is 0.294 . The result of the study indicated whether variable of reading comprehension improve significantly to the variable of vocabulary mastery of the students.

To interpret the result of analysis, criterion proposed by Djiwandono (1996:134) as shown in Table 1 was used.

Table 1

Correlated Interpretation

\begin{tabular}{|c|c|l|}
\hline NO & SCORE & \multicolumn{1}{|c|}{ INTERPRETATION } \\
\hline 1 & $0,80-1,00$ & Very high correlation \\
\hline 2 & $0,60-0.80$ & High correlation \\
\hline 3 & $0,40-0,60$ & Satisfactory \\
\hline 4 & $0,20-0,40$ & Low correlation \\
\hline 5 & $0,00-0,20$ & Very low correlation \\
\hline
\end{tabular}

\section{RESULTS}

The analysis is aimed to see the results of scores of reading comprehension and vocabulary mastery variables achieved from 45 students as a research sample. The scores of reading comprehension are tabulated as variable $\mathrm{X}$ or independent variable, and the scores of vocabulary mastery are tabulated as variable $\mathrm{Y}$ or dependent variable.

The scores of reading comprehension as shown on table 2 delivered total score 2714 and the scores of vocabulary mastery delivered total score 2856 . With 45 students as a sample, the variable reading comprehension delivered the average score 60.31 and the variable vocabulary mastery delivered the average score 63.46. It is clear that the average score of the dependent variable of vocabulary mastery is higher than the 
average score of the independent variable of reading comprehension. In addition, the variable reading comprehension delivered the total $X$ squared $\left(X^{2}\right)=166900$ and the variable vocabulary mastery delivered the total $\mathrm{Y}$ squared $\left(\mathrm{Y}^{2}\right)=185518$. To prove whether reading comprehension improves significantly toward vocabulary mastery or not, the researcher needs to process the scores of both variables using r-test formula and to test the hypothesis. The procedures to process of the statistic data on the r-test of Product Moment formula appears in the following section.

To see correlation of reading comprehension to vocabulary mastery of the students, the calculation of r-test formula of Product Moment is done with the formula as follows:

$$
\begin{aligned}
r_{X Y} & =\frac{N \sum X Y-\left(\sum X\right)\left(\sum Y\right)}{\sqrt{\left\{N \sum X^{2}-\left(\sum X\right)^{2}\right\}\left\{N \sum Y^{2}-\left(\sum Y\right)^{2}\right\}}} \\
& =\frac{45 \times 175209-(2174)(2856)}{\sqrt{\left\{45 \times 166900-(2174)^{2}\right\}\left\{45 \times 185518-(2856)^{2}\right\}}} \\
& =\frac{7884405-7749827}{\sqrt{\{7510500-7365796\}\{8348299-8153880\}}} \\
& =\frac{134578}{\sqrt{\{144704\}\{194419\}}} \\
& =\frac{134578}{\sqrt{28133134624}} \\
& =\frac{134578}{167729349} \\
& =0,802
\end{aligned}
$$

By doing $r$ test calculation, the researcher found $r$ value $=0.802$. Then, this result is compared to the $\mathrm{r}$ table with $\mathrm{N}$ (total of sample) $=45$ and $\mathrm{p}=0.05$ or $\alpha=5 \%$. To do this, the researcher used $\mathrm{r}$ table on $\mathrm{N}=45$ and $\mathrm{p}=0.05$. Based on the criteria, the researcher found the $r$ table value on $N=45$ and $p=0.05$ is 0.294 . The result of $r$ table is compared to the $r$ value.

\section{DISCUSSION}

The results of r-test calculation of reading comprehension to vocabulary mastery by r-test formula, then, is obtained to test the hypothesis testing. This procedure means 
IJOTL TL, Vol. 3, No. 3, September 2018

p ISSN: 2502 2326; e ISSN: 2502 8278

Http://ijolt1.pusatbahasa.or.id; Email: ijolt1@gmail.com

Center of Language and Culture Studies, Surakarta, Indonesia

Armadi, Samsu. 2018. Reading Comprehension and Vocabulary Mastery of the Sixth Graders of SDN 03 Tenggarong. IJOTL TL (2018), 3(3): 123 132. DOI: 10.30957/ijotl tl.v3i3.503.

that the result of r-test calculation as the basis of the interpretation of the result of the hypothesis testing.

The working hypothesis $(\mathrm{Ha})$ of the study reads as: "Reading comprehension improves significantly to vocabulary mastery of the students." To test the hypothesis, the working hypothesis is formulated first into the null hypothesis (Ho). The formulated Ha into Ho is needed because the researcher should be in neutral opinion. This means that before testing the hypothesis, the researcher has to put his neutral position and does not show any prediction on the result of the testing. Therefore, the hypothesis is stated in the negative form. The Ho of this study then reads as: "Reading comprehension does not improve significantly to vocabulary mastery of the students."

The comparison between $r$ table and $r$ value on $\mathrm{N}=45$ and $\mathrm{p}=0.05$ used in this study, indicates that $r$ value $(0.802)$ is higher $(>)$ than $r$ table $(0.294)$. This means that Ho is rejected and $\mathrm{Ha}$ is received. The result implies that the Ho that reads: "Reading comprehension does not improve significantly to vocabulary mastery of the students" is considered not true.

From the result of data analysis under study, the answer to the research problem can be stated as: "Reading comprehension relates significantly to vocabulary mastery." In other words, the higher scores on reading comprehension allows higher scores on vocabulary mastery.

\section{CONCLUSION}

The result of data analysis using Product Moment Formula by Carl Pearson, it showed that reading comprehension improved significantly vocabulary mastery of the students. It can be seen from the result of calculation by Product Moment Formula that achieved the correlation coefficient 0.802. it meant that reading comprehension achievement has very high correlation to vocabulary mastery of the students. By comparing to the value of r-table at 0.05 significance level and $\mathrm{N}=45$, it showed $\mathrm{r}$ value of calculation was greater than r-table (0.294) that indicated the significant correlation between reading comprehension to vocabulary mastery of the students.

\section{REFERENCES}

Abort, Gerry et. al. 1981. The Teaching of English as An International Language. London: Collin Glasgow \& London P.

Baudion, Margareth, et. al. 1977. Reader's Choice. Canada: The University Press of Michigan.

Best, John W. 1981. Research in Education. New Jersey: Englewood Cliffs. Prentice Hall Inc.

Budiharso, Teguh. 2004. Prinsip dan Strategi Pengajaran Bahasa. Surabaya: Lutfansah Mediatama.

Cobuild, Collins. 1996. Learner's Dictionary, Helping Learners with Real English. London: Harper Collins Publisher.

Djamarah, Syaiful Bahri. 2002. Psikologi Belajar. PT Rineka Cipta: Jakarta.

Djiwandono, Soenardi. 1996. Tes Bahasa dalam Pengajaran. Bandung: Penerbit ITB Bandung. 
IJOTL $\sim$ TL, Vol. 3, No. 3, September 2018

p ISSN: 2502 2326; e ISSN: 2502 8278

Http://ijolt1.pusatbahasa.or.id; Email: ijolt1@gmail.com

Center of Language and Culture Studies, Surakarta, Indonesia

Armadi, Samsu. 2018. Reading Comprehension and Vocabulary Mastery of the Sixth Graders of SDN 03 Tenggarong. IJOTL TL (2018), 3(3): 123 132. DOI: 10.30957/ijotl tl.v3i3.503.

Dwyer, Margareth A. 1983. Some Strategies for Improving Reading Efficiency. English Teaching Forum Vol. XXI.

Grellet. 1984. developing Reading Skills. Cambridge: Cambridge University Press.

Hornby, AS. 1995. Oxford Advanced Learner's Dictionary of Current English. London: Oxford University Press.

Indrakusuma, Amir Daien. 1973. Pengantar Ilmu Pendidikan. Surabaya: Usaha Nasional.

Ishak, Muh. 1994. Teaching Reading Comprehension by Using the Phrase Reading Technique at the Second Year Students of SMPN 7 Tenggarong. Tenggarong: Tenggarong University.

Lado, MJ. 1996. Common Error in English. Jakarta: CV. Tulus Jaya.

Moore, Gary W. 1983. Developing and Evaluating Educational Research. Toronto: Little Brown Company.

Sardiman, AM. 1992. Interaksi dan Motivasi Belajar Mengajar: Pedoman Bagi Guru dan Calon Guru. Jakarta: Rajawali Pers.

Watson, Owen. 1976. Longman Modern English Dictionary. London: Hazel Watson.

Yerkes, D. 1986. Webster's Encyclopedia Unbridged Dictionary of English Language. New York: Portland House. 